\title{
What should be a gas-engine locomotive
}

\author{
Evgeny Kossov ${ }^{1}$, Ivan Andronchev ${ }^{2}$, Vitaliy Asabin ${ }^{2}$, Anatoly Silyuta ${ }^{1}$, and Lidia Kossova ${ }^{1}$ \\ ${ }^{1}$ Joint Stock Company Railway Research Institute JSC (VNIIZHT), 3rd Mytishchinskaya St., 10, bld. \\ 3, Moscow, 129851, Russia \\ ${ }^{2}$ Samara State Transport University (SSTU), Svoboda Street, 2V, Samara, 443066, Russia
}

\begin{abstract}
Today, no one doubts the necessity of widespread applying of gas fuel both in industry and in transport. The price, environmental safety and availability of this type of fuel play a crucial role. Russian Railways has also taken a number of decisions to develop the design and construction of gas-fueled locomotives. The work is being carried out in two directions: locomotives will be created that run on gas fuel using gas turbine and gas piston engines with full replacement of diesel fuel, as well as gas locomotives with diesel engines that run on a gas-diesel cycle. The latter are attractive because the gas-diesel engine has higher technical and economic characteristics and can be easily transformed into a locomotive running on diesel fuel, which can be of strategic importance.
\end{abstract}

\section{Introduction}

In Gas-piston engines were created in the last century and are used in road transport and stationary installations. There are examples of using gas-piston engines on diesel locomotives. In Russia, there is a gas thermal locomotive TEM19 with a gas-engine locomotive $8 \mathrm{GCHN} 21$ / 26. It is planned to produce a mainline diesel locomotive with a gas piston engine. When converting a diesel engine to a gas-piston engine, it is necessary to solve a number of problems related to stable ignition of the air-gas mixture and ensuring acceptable parameters of the working process. It is necessary to increase the idle speed of the crankshaft, reduce the compression ratio of the working fluid in the cylinder, use pre-chambers to ensure ignition of the gas-air mixture, apply air throttling at the engine inlet and other solutions that do not increase the technical performance of engines. To use a locomotive that runs only on gas fuel, it is necessary to purchase a new engine, since unlike a gas-diesel engine, it is not possible to convert a diesel engine into a gas-piston engine during modernization at a depot or at a repair plant. The lack of fuel equipment does not allow to transfer a gas piston engine to a diesel engine. However, at the low price of gas fuel, the absolute replacement of diesel fuel with gas makes this option of converting an engine to gas fuel very attractive.

We also have experience in the creation and use of gas-fueled diesel locomotives using the gas-diesel cycle. The mainline diesel locomotives 2TE116G, 2TE10G and shunting diesel locomotives TEM2G and TEM18G with diesel engines operating on the gas-diesel cycle were created [2]. Due to historical events, gas mains were not brought to commercial production. The TEM18G shunting diesel locomotive was brought to industrial production,

* Corresponding author: voropaevamv@ yandex.ru 
but for a number of reasons it was not distributed. The main circumstance was the unavailability of the infrastructure for providing diesel locomotives with gas fuel, another factor is the low (30-40\%) degree of substitution of diesel fuel with gas. With such a low degree of substitution of diesel fuel, it may be more advantageous to use diesel locomotives with gas piston engines. Of course, the question arises - is the low level of gas substitution of diesel fuel a fundamental drawback of the gas-diesel cycle.

In our opinion, this situation arose due to the fact that in the technical requirements for gas-diesel engines there is a requirement for an instant transition to work from gas to diesel fuel and vice versa. This means that regular injectors should be used on the diesel engine, and they must ensure the supply of the ignition portion of fuel in the gas-diesel cycle at all operating modes, which is practically impossible. We believe that the transition from gas to liquid fuel should be accompanied by a change nozzles. In this case, when working on the gas-diesel cycle, it is possible to ensure the operation of the diesel engine in all modes, including starting and idling, and a high (85-90\%) degree of replacement of diesel fuel.

\section{Technical and economic assessment of shunting diesel locomotives operating on diesel and gas fuels}

There are well-developed methods for comparing the technical and economic characteristics of installations operating on alternative fuels [3]. In our case, it is enough to make an approximate assessment of the effectiveness of varying degrees of substitution of fuel with gas.

It is proposed to compare the cost of purchasing fuel for diesel locomotives running on diesel fuel, a mixture of diesel and gas fuel, and gas fuel. The objects considered are the locomotives TEM18, TEM18D, TEM19 and the projected TEM18GM.

Diesel locomotives TEM18, TEM18D and TEM18DM use diesel 1 PD4 in a purely diesel version (TEM18) and when using a gas-diesel cycle with different degrees of substitution of diesel fuel with gas (TEM18G and TEM18GM). On the locomotive TEM19-gas fuel.

When comparing diesel locomotives it is accepted:

- the rated power of the compared diesel locomotives is the same;

- all diesel locomotives operate in the same modes;

- the magnitude of the costs of creating infrastructure to ensure the supply of diesel locomotives with gas fuel, and the preparation of depot facilities were not taken into account;

- the cost of purchasing a new gas-piston engine and upgrading a diesel engine to a gasdiesel engine is not taken into account;

- the cost of the gas equipment and the equipment ensuring safety of operation of the locomotive is accepted identical for the locomotives working on gas;

- the cost of diesel fuel and natural gas fuel is 54,000 and 22,000 rubles per ton, respectively;

- the calorific value of fuel and natural gas accepted 42700 and $48000 \mathrm{~kJ} / \mathrm{kg}$, respectively.

Table 1 shows the relative operating times of shunting locomotives at the positions of the driver's controller. The first mode corresponds to the average statistical data on the operation of shunting diesel locomotives on a network of roads [4-6]. The second and third modes correspond to hill work and work on the hood [7-9]. 
Table 1. Operating modes of shunting diesel locomotives.

\begin{tabular}{|c|c|c|c|c|c|c|c|c|c|c|}
\hline \multicolumn{2}{|c|}{ Controller position } & 0 & 1 & 2 & 3 & 4 & 5 & 6 & 7 & 8 \\
\hline \multirow{3}{*}{$\begin{array}{l}\text { Relative } \\
\text { work } \\
\text { time, } \%\end{array}$} & 1 & $\begin{array}{l}0 \\
\dot{f}\end{array}$ & $\stackrel{\vartheta}{\dot{r}}$ & 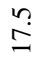 & $\stackrel{ナ}{\stackrel{\overbrace{}}{I}}$ & $\underset{\infty}{\infty}$ & F & $\stackrel{\sim}{=}$ & ? & กั \\
\hline & 2 & $\stackrel{m}{n}$ & $\overline{\mathrm{I}}$ & ત્ & $\begin{array}{l}\infty \\
\infty \\
\infty \\
\infty\end{array}$ & $\stackrel{\infty}{\sim}$ & $\stackrel{\text { ô }}{i \dot{i n}}$ & $\stackrel{8}{0}$ & กั & $\stackrel{+}{-}$ \\
\hline & 3 & $n$ & $\mathfrak{n}_{0}^{n}$ & $\stackrel{0}{\infty}$ & n' & $n$ & $\stackrel{n}{\stackrel{n}{m}}$ & $\underset{\sim}{\stackrel{\infty}{\sim}}$ & ñ & $\underset{\sim}{\text { ते }}$ \\
\hline
\end{tabular}

Table 2. Shows the calculated characteristics of the PD1 diesel engine and the performance of the TEM18 shunting locomotive in the selected operating modes.

Table 2. Calculated characteristics of the PD1 diesel engine and the performance of the TEM18 shunting locomotive in the selected operating modes.

\begin{tabular}{|c|c|c|c|c|c|c|c|c|c|c|}
\hline \multicolumn{2}{|c|}{$\begin{array}{l}\text { Controller } \\
\text { position }\end{array}$} & 0 & 1 & 2 & 3 & 4 & 5 & 6 & 7 & 8 \\
\hline \multicolumn{2}{|c|}{ 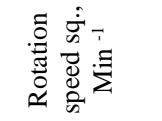 } & ః్ల & ః్ల & ల్ల & : & ळे & $\underset{+}{\stackrel{+}{f}}$ & $\frac{n}{n}$ & $\bar{b}$ & $\stackrel{\Re}{n}$ \\
\hline \multicolumn{2}{|c|}{ 苛茛 } & ' & $\underset{E}{己}$ & $\stackrel{\varrho}{\exists}$ & 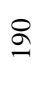 & $\stackrel{৯}{\circ}$ & $\stackrel{\circ}{\ni}$ & 号 & $\stackrel{\otimes}{\infty}$ & $\begin{array}{l}\infty \\
\infty \\
\infty\end{array}$ \\
\hline \multicolumn{2}{|c|}{ 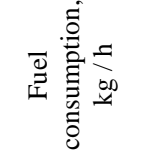 } & 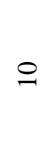 & ㄱ. & लె & ơ & $\widetilde{\sigma}$ & $\infty$ & 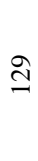 & $\underline{6}$ & ते \\
\hline \multirow{3}{*}{ 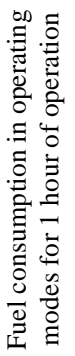 } & - & $\begin{array}{l}\stackrel{0}{n} \\
\stackrel{f}{+}\end{array}$ & $\stackrel{\infty}{0}$ & $\begin{array}{l}0 \\
\text { in }\end{array}$ & $\underset{\infty}{\stackrel{\infty}{\infty}}$ & $\begin{array}{l}n \\
\stackrel{n}{n}\end{array}$ & in & $\stackrel{n}{n}$ & ga & $\underset{\delta}{F}$ \\
\hline & $N$ & $\frac{m}{n}$ & $\stackrel{\stackrel{\sim}{+}}{i}$ & in & $\underset{+}{\tilde{r}}$ & $\stackrel{\bullet}{r}$ & $\stackrel{\infty}{\stackrel{\infty}{+}}$ & $\underset{0}{\stackrel{0}{*}}$ & ?ֶ: & $\begin{array}{l}\infty \\
i \\
i\end{array}$ \\
\hline & $n$ & $n$ & $\ddot{m}$ & $\stackrel{n}{i}$ & $\tilde{n}$ & $\bar{m}$ & $\stackrel{\circ}{\dot{m}}$ & $\vec{\infty}$ & $\begin{array}{l}\stackrel{0}{\infty} \\
0 \\
0\end{array}$ & ñ \\
\hline
\end{tabular}

Accordingly, the fuel consumption rate was: $30.6 ; 28.1 ; 30.1 \mathrm{~kg}$ per hour of operation, the cost of fuel was: $1653 ; 1517 ; 1641 \mathrm{r} / \mathrm{h}$.

Table 3 shows the characteristics and performance of the TEM18G diesel locomotive in the same operating modes. 
Table 3. Characteristics and performance of the TEM18G diesel locomotive in the same operating modes.

\begin{tabular}{|c|c|c|c|c|c|c|c|c|c|c|}
\hline \multicolumn{2}{|c|}{$\begin{array}{l}\text { Controller } \\
\text { position }\end{array}$} & 0 & 1 & 2 & 3 & 4 & 5 & 6 & 7 & 8 \\
\hline \multicolumn{2}{|l|}{ 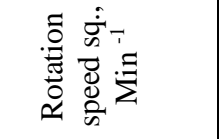 } & శ్ల & \& & ల్ల & : & ஓి & $\underset{⿱}{\stackrel{+}{f}}$ & 운 & $\overline{8}$ & $\stackrel{\cap}{n}$ \\
\hline \multicolumn{2}{|l|}{ 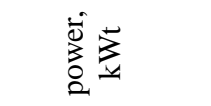 } & ' & in & 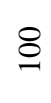 & @ & ঐे & $\stackrel{\bigcirc}{\ni}$ & 움 & $\stackrel{8}{8}$ & $\underset{\infty}{\infty}$ \\
\hline \multicolumn{2}{|l|}{ 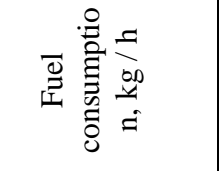 } & 으 & ๙ & กี & fo & $\stackrel{\sim}{\tilde{n}}$ & $\stackrel{\infty}{\sim}$ & $\stackrel{+}{\tilde{\lambda}}$ & $m$ & లి \\
\hline \multicolumn{2}{|l|}{ 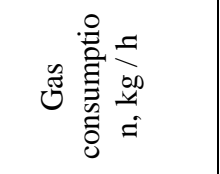 } & ' & ' & ' & 1 & $\begin{array}{l}+ \\
\infty \\
+\end{array}$ & 8 & $\hat{a}$ & $\stackrel{\varrho}{=}$ & $\begin{array}{l}+\sigma^{\circ} \\
\stackrel{n}{n}\end{array}$ \\
\hline \multirow{3}{*}{ 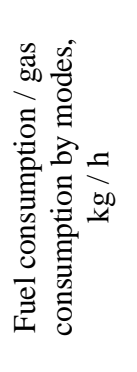 } & - & \begin{tabular}{l}
$\stackrel{0}{*}$ \\
\multirow{f}{*}{}
\end{tabular} & $\stackrel{\infty}{0}$ & $\begin{array}{l}0 \\
i\end{array}$ & o & 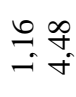 & $\stackrel{+}{*}$ & 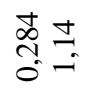 & $\begin{array}{l}\delta \\
0 \\
0 \\
0 \\
0 \\
0\end{array}$ & $\begin{array}{ll}8 & = \\
0 & 0 \\
0 & 0\end{array}$ \\
\hline & 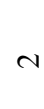 & $\ddot{n}$ & $\stackrel{\text { i }}{\mathrm{T}}$ & $\tilde{n}$ & ô & $\begin{array}{l}8= \\
\stackrel{0}{0} \\
0\end{array}$ & $\hat{\circ} \tilde{m}$ & $\begin{array}{l}1 \\
0 \\
0 \\
0\end{array}$ & 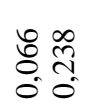 & 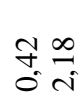 \\
\hline & 3 & $\ddot{n}$ & $\dot{m}$ & $\stackrel{n}{i}$ & $\stackrel{n}{n}$ & 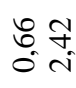 & $\begin{array}{l}\sqrt{1} \\
\text { d } \\
0 \\
0 \\
0\end{array}$ & $\bar{n} \overline{0}$ & $\begin{array}{l}\frac{n}{2} 0 \\
0 \\
0 \\
0\end{array}$ & $\begin{array}{l}\hat{a} \\
\hat{\sigma} \\
\text { in }\end{array}$ \\
\hline
\end{tabular}

Table 4 shows the hourly consumption of diesel and gas fuel, the degree of substitution of fuel by gas, the cost of fuel per hour of operation of the TEM18G diesel locomotive in selected modes, and cost savings for each hour of operation compared to the TEM18 diesel locomotive.

Table 4. Hourly consumption of diesel fuel, gas fuel, degree of substitution, fuel cost and cost savings per hour of work.

\begin{tabular}{|c|c|c|c|c|c|}
\hline \multirow{2}{*}{$\begin{array}{c}\text { Diesel } \\
\text { locomotive } \\
\text { TEM18G }\end{array}$} & $\begin{array}{c}\text { Hourly } \\
\text { consumption of } \\
\text { fuel / gas, kg / h }\end{array}$ & Substitution, \% & \multicolumn{2}{|c|}{$\begin{array}{c}\text { The cost of fuel and } \\
\text { gas }\end{array}$} & \multirow{2}{*}{$\begin{array}{c}\text { Savings, } \\
\text { RUB / h }\end{array}$} \\
\cline { 4 - 5 } & $21.49 / 9.0$ & 29 th & 1358 & 18 & 295 \\
\hline Mode 1 & $219 / \mathrm{h}$ & $\%$ & \\
\hline Mode 2 & $19.0 / 8.63$ & 31 & 1216 & 20 & 301 \\
\hline Mode 3 & $17.02 / 12.43$ & 41 & 1192 & 27.4 & 449 \\
\hline
\end{tabular}

Table 5 shows the characteristics and performance of the TEM19 locomotive in the same operating modes [10]. 
Table 5. Characteristics and performance of the TEM19 locomotive in the same operating modes.

\begin{tabular}{|c|c|c|c|c|c|c|c|c|c|c|}
\hline \multicolumn{2}{|c|}{ Controller position } & 0 & 1 & 2 & 3 & 4 & 5 & 6 & 7 & 8 \\
\hline \multicolumn{2}{|c|}{$\begin{array}{l}\text { Rotation speed sq., } \\
\text { Min }^{-1}\end{array}$} & 600 & 650 & 700 & 750 & 800 & 850 & 900 & 950 & 1000 \\
\hline \multicolumn{2}{|c|}{ power, $\mathrm{kWt}$} & - & fifty & 110 & 190 & 290 & 410 & 540 & 680 & 880 \\
\hline \multicolumn{2}{|c|}{$\begin{array}{l}\text { Gas consumption, } \\
\mathrm{kg} / \mathrm{h}\end{array}$} & 24 & thirty & 44 & 58 & 78 & 96 & 103 & 142 & 171 \\
\hline \multirow{3}{*}{$\begin{array}{c}\text { Gas } \\
\text { consumption } \\
\text { in modes, kg } \\
/ \mathrm{h} \\
\end{array}$} & 1 & 9.94 & 1,57 & 7.7 & 10.15 & 6.7 & 4.0 & 1.43 & 0.43 & 0.342 \\
\hline & 2 & 11.3 & 3.9 & 7.15 & 5.13 & 4.41 & 4.93 & 0.11 & 0.29 & 2,39 \\
\hline & 3 & 12.1 & 5.28 & 3,8 & 3.19 & 3.8 & 3.4 & 2.59 & 0.78 & 5.5 \\
\hline
\end{tabular}

Table 6 shows the hourly consumption of diesel and gas fuel, the degree of fuel replacement with gas, the cost of fuel per hour of operation of the TEM19 locomotive in the selected modes and cost savings for each hour of operation compared to the TEM18 locomotive.

Table 6. Hourly consumption of diesel and gas fuel, the degree of fuel replacement with gas, the cost of fuel per hour of operation of the TEM19 locomotive in the selected modes and cost savings for each hour of operation compared to the TEM18 locomotive.

\begin{tabular}{|c|c|c|c|}
\hline $\begin{array}{c}\text { Diesel locomotive } \\
\text { TEM19 }\end{array}$ & $\begin{array}{c}\text { Gas consumption, kg / } \\
\mathrm{h}\end{array}$ & $\begin{array}{c}\text { The cost of } \\
\text { gas, rub. }\end{array}$ & Savings, RUB / h \\
\hline Mode 1 & 42 & 924 & 729 \\
\hline Mode 2 & 39.6 & 871 & 646 \\
\hline Mode 3 & 40.3 & 887 & 754 \\
\hline
\end{tabular}

Table 7 shows the characteristics and performance of the TEM18GM diesel locomotive in the same operating modes.

Table 7. Characteristics and performance of the TEM18GM diesel locomotive in the same operating modes.

\begin{tabular}{|c|c|c|c|c|c|c|c|c|c|}
\hline $\begin{array}{l}\text { Controller } \\
\text { position }\end{array}$ & 0 & 1 & 2 & 3 & 4 & 5 & 6 & 7 & 8 \\
\hline $\begin{array}{l}\text { Rotation } \\
\text { speed sq., } \\
\text { Min }^{-1}\end{array}$ & $\underset{\sim}{\stackrel{\sim}{\sim}}$ & ఫ্ల & ల్లి & : & ळे & $\underset{⿱}{\stackrel{f}{f}}$ & in & $\overline{8}$ & $\stackrel{ }{\circ}$ \\
\hline power, $\mathrm{kWt}$ & , & 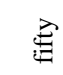 & $\stackrel{\varrho}{=}$ & 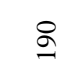 & ஓे & $\stackrel{\ominus}{\ni}$ & 吕 & $\stackrel{0}{0}$ & $\underset{\infty}{\infty}$ \\
\hline $\begin{array}{c}\text { Fuel } \\
\text { consumptio } \\
\mathrm{n}, \mathrm{kg} / \mathrm{h}\end{array}$ & $N$ & $i$ & m & in & $r$ & $=$ & $\stackrel{2}{2}$ & 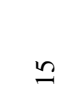 & $\stackrel{\infty}{-}$ \\
\hline $\begin{array}{c}\text { Gas } \\
\text { consumptio } \\
\mathrm{n}, \mathrm{kg} / \mathrm{h}\end{array}$ & in & \pm & $\stackrel{\sim}{\sim}$ & q & in & $\bar{\infty}$ & $\stackrel{2}{2}$ & $\stackrel{\overbrace{}}{2}$ & 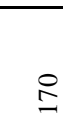 \\
\hline
\end{tabular}




\begin{tabular}{|c|c|c|c|c|c|c|c|c|c|}
\hline $\begin{array}{l}\text { Fuel and } \\
\text { gas } \\
\text { consumptio } \\
\mathrm{n}, \mathrm{kg} / \mathrm{h} \\
\text { Mode } 1\end{array}$ & స̃ & 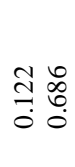 & 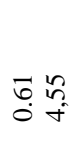 & $\stackrel{n}{\infty} \stackrel{0}{\circ}$ & $\begin{array}{l}\sigma \\
0 \\
0\end{array}$ & 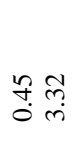 & 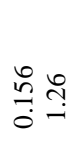 & $\begin{array}{l}\text { 莳 } \\
0 \\
0 \\
0\end{array}$ & $\overbrace{0}^{\infty} \stackrel{+}{0}$ \\
\hline Mode 2 & 0. & $\stackrel{3}{0}:$ & हैं ָे & $\underset{f}{J}$ & $\vec{J} \dot{0}$ & กุ. & $\begin{array}{l}1 \\
0 \\
0 \\
0 \\
0\end{array}$ & ֻ & $\overbrace{\substack{n \\
\hdashline}}^{\infty}$ \\
\hline Mode 3 & $=4$ & $\underset{0}{*} \stackrel{m}{i}$ & $\stackrel{m}{0} \underset{\sim}{\pi}$ & 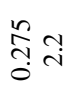 & $\begin{array}{ll}n \\
m \\
0 \\
0\end{array}$ & 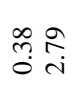 & 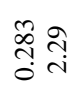 & $\begin{array}{ll}0 \\
0 \\
0 \\
0\end{array}$ & 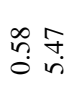 \\
\hline
\end{tabular}

Table 8 shows the hourly consumption of diesel and gas fuel, the degree of fuel replacement with gas, the cost of fuel per hour of operation of the TEM18GM locomotive in the selected modes and cost savings for each hour of operation compared to the locomotive TEM18 and TEM19 (in brackets).

Table 8. Hourly consumption of diesel and gas fuel, the degree of fuel replacement with gas, the cost of fuel per hour of operation of the TEM18GM locomotive in the selected modes and cost savings for each hour of operation compared to the locomotive TEM18 and TEM19 (in brackets).

\begin{tabular}{|c|c|c|c|c|}
\hline $\begin{array}{c}\text { Diesel } \\
\text { locomotive } \\
\text { TEM18GM }\end{array}$ & $\begin{array}{c}\text { Hourly } \\
\text { consumption of } \\
\text { fuel / gas, kg/ } \\
\text { h }\end{array}$ & $\begin{array}{c}\text { Substitution of } \\
\text { diesel fuel, } \%\end{array}$ & $\begin{array}{c}\text { The cost } \\
\text { of fuel } \\
\text { and gas, } \\
\text { rub. }\end{array}$ & $\begin{array}{c}\text { Savings } \\
\text { per hour, } \\
\text { rub. }\end{array}$ \\
\hline Mode 1 & $3.83 / 24.87$ & 87.5 & 754 & $899(170)$ \\
\hline Mode 2 & $3.38 / 22.2$ & 88 & 671 & $846(200)$ \\
\hline Mode 3 & $3.76 / 23.63$ & 87.6 & 723 & $918(164)$ \\
\hline
\end{tabular}

Comparison of the cost of fuel per hour of operation of the compared diesel locomotives in the selected operating modes is shown in Figure 1. 


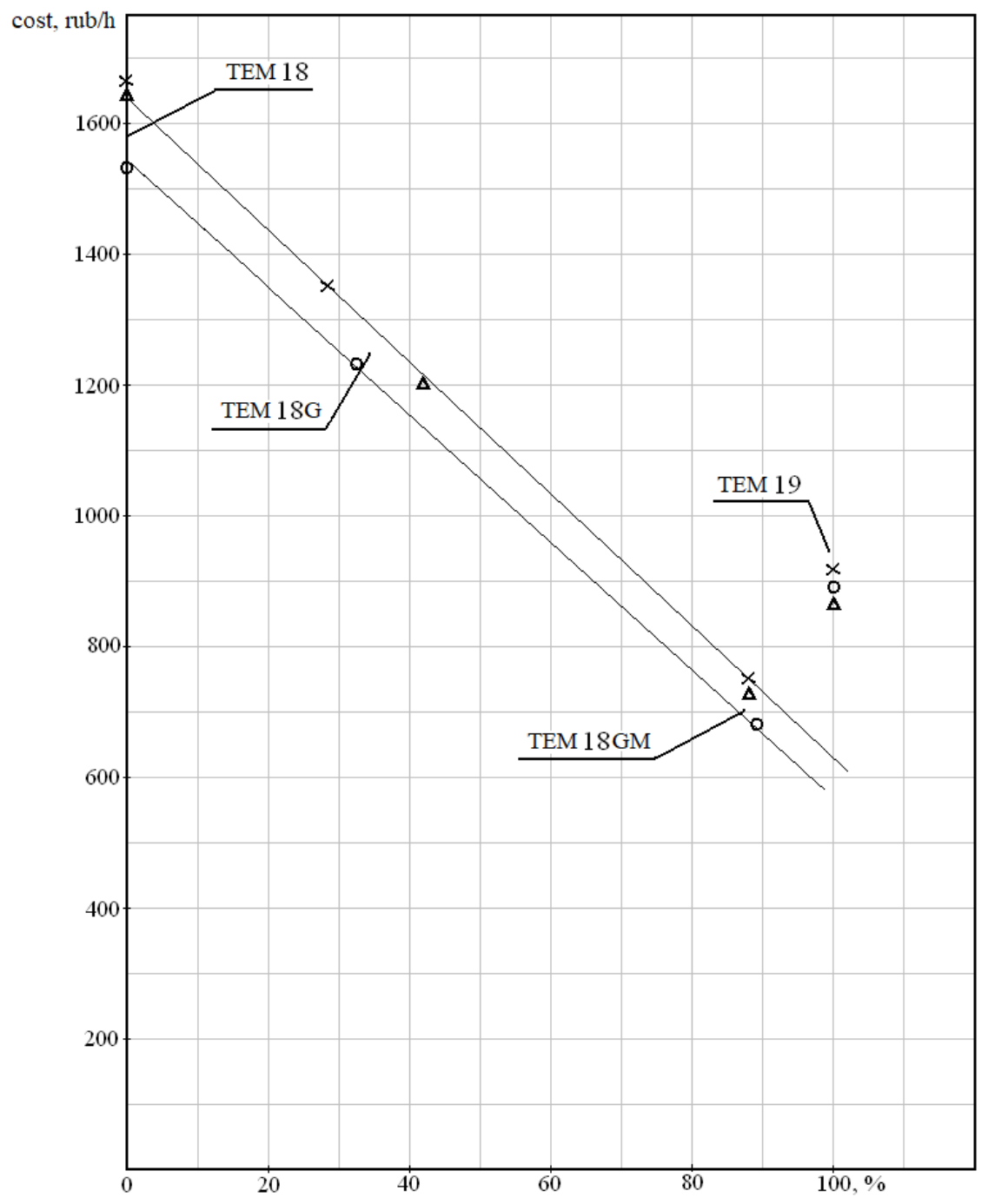

$\mathrm{O}, \boldsymbol{\Delta}, \times-1,2$ and 3 modes respectively

Fig 1. The cost of fuel per hour of operation, depending on the degree of substitution of fuel with gas and the mode of operation of the locomotive in the average operating mode.

We believe that the transition from gas to liquid fuel should be accompanied by a change in nozzles. In this case, when working on the gas-diesel cycle, it is possible to ensure the operation of the diesel engine in all modes, including starting and idling. It is assumed that a special nozzle will provide a minimum supply of ignition fuel (0.1-0.05g for PD4 or D49 diesel engines) with a torch $20-30 \mathrm{~mm}$ long, with good atomization in all operating modes, with a feed duration of 5-6 degrees of crankshaft rotation $[11,12]$. In this case, the ignition process of the mixture of air and gas will be significantly reduced and the nature of combustion will change. Combustion will proceed from a relatively small ignition zone by moving the combustion front along the compression chamber. Steady movement of the combustion front will occur when the specified stoichiometric composition of the mixture is provided [13-15]. The combustion front of the main part of the mixture will spread in the 
combustion chamber at a speed close to $2000 \mathrm{~m} / \mathrm{s}$, which can cause a sharp increase in pressure in the combustion chamber. To avoid this, it is necessary to shift the beginning of combustion to the top dead center or slightly beyond it, but so as not to bring the combustion process to the expansion process. To do this, it is necessary to ensure very high accuracy in the implementation of a given phase of fuel supply and the quality of the stoichiometric composition of the mixture.

Such an organization of the combustion process will significantly reduce the mass of the ignited portion of fuel and ensure an acceptable level of maximum combustion pressure. The accuracy of the phase (moment) of fuel supply can be provided by the electronic fuel injection control system (EFICS), produced by "PPP Dieselavtomatika" LLC, Saratov.

Typically, when the PD4 diesel engine is idling, the excess air coefficient is 10-11. When working on three cylinders, its value will be 5-5.5. If you use a gas-diesel cycle with a share of ignition fuel of $10 \%$, then the coefficient of excess air of the gas-air mixture when working on three cylinders will be 4.3 , which will not ensure stable ignition of the mixture.

The possibility of further reducing the number of working cylinders to ensure stable combustion requires special consideration, therefore, it is possible to ensure the amount of air in the cylinders at the beginning of compression to ensure that the diesel engine idles. On gas piston engines, this problem is solved by throttling the air at the engine inlet. One way to change the stoichiometric ratio can be to reduce the number of working cylinders. The electronic fuel injection control system allows, without shutting off individual cylinders, to increase the interval between individual working strokes during operation of all cylinders by changing the order of operation of the cylinders. For example, when operating a 1PD4 diesel engine, to increase the interval between flashes from 120 degrees of crankshaft rotation to 240 , it is enough to apply the operating procedure $1,5,4,6,2,3$ instead of the accepted operating procedure 1,3,5.4.6,2. In this case, the amount of air in the cylinder at the beginning of compression will remain the same, and the cyclic supply will almost double. You can increase the interval between working cylinders up to 480 degrees of crankshaft rotation. Then the stoichiometric ratio will be reduced four times as compared to the initial one and the condition for ignition and combustion of the gas-air mixture will be ensured. The organization of the diesel engine with such an interval of cylinder operation requires a thorough check. Therefore, it may be necessary to use, when working on gas, an additional decrease in the stoichiometric ratio by reducing air pressure at the beginning of compression due to throttling at the inlet to the diesel engine.

When regulating the air supply by throttling on an engine with a gas-diesel cycle, a situation may arise in which, due to a decrease in the temperature of the mixture, stable ignition of the fuel ignition portion will not be ensured. Apparently, diesels equipped with a charge air cooling system do not have this problem.

We assume that when the air charge is reduced by throttling at the engine inlet, it is cooled due to adiabatic expansion in the cylinder at the filling stroke. Assume the temperature and pressure of the external air $-40^{\circ} \mathrm{C}$. and $101.4 \mathrm{kPa}$. Due to the throttling valve the pressure at the end of filling $\mathrm{P}_{\mathrm{a}}$ to $50 \mathrm{kPa}$. Assume that the piston on the filling line adiabatic expansion work is done on the pressure $\mathrm{P}_{0}$ to a pressure $\mathrm{P}_{\mathrm{a}}$. With a decrease in pressure from 101.4 to $50 \mathrm{kPa}$ with an adiabatic index for air 1.41, the temperature will decrease 0.817 times.

If there is a cooling system, then the position, then after the throttle valve, where the temperature does not change, the air passes the charge air cooler and with a cooler efficiency coefficient $\mathrm{C}_{\text {хл }}=0,8$ and a coolant temperature $\mathrm{T}_{\text {охл }}=50^{\circ} \mathrm{C}$, the temperature at the inlet to the cylinders will be:

$$
\begin{gathered}
T_{o}=T_{o}-C_{\text {хл }} \cdot\left(T_{o}-T_{\text {охл }}\right) \text { при } \mathrm{T}_{\text {охл }}=333 \mathrm{~K} \\
T_{o}=233-0.8 \cdot(233-333)=313 K
\end{gathered}
$$


$\mathrm{T}_{\mathrm{a}}=313 * 0,817=255 \mathrm{~K}$.

The temperature at the end of compression will be:

$\mathrm{T}_{\mathrm{c}}=732 \mathrm{~K}$.

At this temperature, self-ignition of the ignition fuel is guaranteed. The given temperature estimate is approximate, since it does not take into account gas exchange processes and exhaust gas bypass into the cylinder during the purge period.

It can be said that during a gas-diesel cycle, a combination of processes may be required to start and idle: shut off the cylinders and throttle the air at the inlet to the diesel engine. The above methods of regulating the operation of engines are used in practice and do not require additional study. When using an electronic injection control system, the development of special algorithms is required that provide the required stoichiometric ratio for all operating modes.

\section{Creation of special nozzles}

Of course, the implementation of the stable operation of the gas-diesel cycle in all operating modes requires the creation of special atomizer nozzles. First of all, it is necessary to formulate the technical requirements for such sprayers. To solve this problem, a mathematical model for calculating the fuel supply process in the fuel supply control system has been created. It is necessary to simulate the control of the fuel supply process in terms of ensuring high-quality injection of the ignition portion of fuel at all operating modes and the formation of a "torch" with a fairly dense spray near the sprayer. It is also necessary to conduct a thorough study of gas exchange processes when the engine is operating in modes with an increased interval between cycles.

\section{Conclusion}

A comparison of the two methods of converting diesel locomotives to gas fuel showed that both methods have a right to exist. However, the use of the gas-diesel cycle is more promising. There are many tasks that must be solved. This includes developing special atomizers, regulating the stoichiometric ratio, developing a special electronic fuel injection control system that controls the supply of fuel and gas separately to each working cylinder, and creating algorithms for controlling a given stoichiometric ratio.

\section{References}

1. V.A. Gapanovich, Railway transport, 9, 35-38 (2017)

2. G.A. Fofanov, D.N. Grigorovich, A.S. Nestrakhov, INTEC, 144 (2008)

3. E.A. Mirenkova, Improving the energy, environmental and economic indicators of power plants operating on alternative fuels derived from natural gas ("NAMI" FGUP, 2019)

4. Operational tests of TEM18G gas and diesel locomotives. Research Institute of Railway Transport, state registration number 01200115547 (2001)

5. D.Ya. Nosyrev, L.S. Kurmanova, S.A. Petukhov, et al., Ecology and Industry of Russia, 23(2), 19-23 (2019) DOI: 10.18412/1816-0395-2019-02-19-23

6. Ye.A. Lazarev, V.S. Murzin, V.Ye. Lazarev, et al., Mechanical Engineering, 13(1), 3643 (2013) 
7. The hourly diesel test mode, corresponding to the average operating mode of the shunting diesel locomotive, All-Union Scientific Research Institute of Railway Transport (AURIRT), Ural Branch, Moscow-Sverdlovsk, 9 (1987)

8. D.Ya. Nossyrev, A.Yu. Balakin, et al., Povolzhye Transport Newsletter, 2(56), 33-38 (2016)

9. L.S. Kurmanova, Povolzhye Transport Newsletter, 6(72), 108-114 (2018)

10. Gas piston engine-generator GDG $800 \mathrm{~T}$, operating Manual/ "Volzhsky diesel named after Maminykh" JSC

11. V.V. Furman, et al., Truck, 4, 38-45 (2013)

12. 2016 GOST R 56286-2014 shunting Locomotives operating on liquefied natural gas

13. V.G. Kamaltdinov, Ye.V. Abeliovitch, Mechanical Engineering, 23 (123), 46-53 (2008)

14. L.S. Kurmanova, Trans-Siberian Buletin, 3(31), 20-27 (2017)

15. A.Yu. Balakin, D.Ya. Nossyrev, L.S. Kurmanova, et al., Dvigatel (Engine)-2018, 48-49 (2018) 